\title{
STRUCTURAL OPTIMIZATION OF NEURAL NETWORK FOR QUALITATIVE EVALUATION METHOD OF IT-INFRASTRUCTURE FUNCTIONING
}

\author{
Yaroslaw Y. Dorogyy, Sergii F. Telenik, Dmytro A. Halushko \\ National Technical University of Ukraine "Kyiv Polytechnic Institute" \\ Vasyl V. Tsurkan \\ Institute of Special Communication and Information Security NTUU "KPI"
}

Background. For today, the unit neural networks are widely used to solve various problems. In this regard, the issue of developing learning algorithm that would be able to optimize the structure of neural networks dynamically is very important. The existence of such a method would allow the researcher to get the structure of the neural network that would be available input data quickly. IT infrastructure allows an organization to deliver IT solutions and services to its employees or customers and is usually internal to an organization and deployed within owned facilities

Objective. In most cases, organizations are able to manage individual elements within their IT infrastructure. But, previously, it is necessary to estimate current quality level of service (QoS) or IT infrastructure functioning generally. In a complex IT infrastructure with mutual influence of its elements it is hard to estimate a quality or its operating.

Method. Taken into a large number of IT infrastructure elements it is important to choose a structure of neural networks automatically. The proposed method makes it possible to control processes inside IT-infrastructure and to form the control actions taking into account the quality of the functioning of IT-infrastructure components which makes it advisable to use a control loop targeted at improving the quality indicators of the performance of the IT-infrastructure.

Results. This paper proposes to use neural networks to evaluate a quality of IT infrastructure functioning. Since the task of determining the structure of the neural network is almost impossible, because it requires a deep analysis of each process taking place in the IT infrastructure, the paper proposes to define the structure of the neural network automatically using structural optimization algorithm of neural network. Series of experiments constructed algorithm that demonstrate the ability to use it in problems of classification of data.

Conclusions. The proposed method makes it possible to control processes inside IT-infrastructure and to form the control actions taking into account the quality of the functioning of IT-infrastructure components which makes it advisable to use a control loop targeted at improving the quality indicators of the performance of the IT-infrastructure. Also the resulting structure of neural network can be used in a quality estimation of functioning of similar IT infrastructure elements. This will allow the service provider "on the fly" construct and retrain its existing models in a shorter period.

Key words: IT infrastructure; neural networks; the control actions; quality estimation.

\section{Introduction}

For a long time, information technologies are used by business companies and at home. Technologies like IPTV, VoIP or $3 \mathrm{G}$ are not only convenient and necessary but profitable. There is a strong competition in this market, so that providers should pay more attention to the opinions of their clients. One way is to improve service quality and hold this level in future, another - is to change states resource dependencies manifest the behavior of the infrastructure. When solving problems as well as maintaining certain parameters of IT infrastructure elements and services on a sufficient quality level of functioning, it is important to ensure and control the required functioning quality of IT infrastructure executive elements. To solve this problem it is necessary to determine whether the system and its modules are in the desired range of quality of functioning, based on data from monitoring of executive modules. In this paper using a neural network as a classifier to determine the quality of provided services is proposed.

For today, the unit neural networks are widely used to solve various problems. In this regard, the issue of developing learning algorithm that would be able to optimize the structure of neural networks dynamically is very important. The existence of such method would allow the researcher to get the structure of the neural network that would be best-answered domain and available input data quickly.

\section{State of art}

IT infrastructure comprises hardware, software, network resources and services required for the functioning. It allows an organization to deliver IT solutions and services to its employees or customers and is usually internal to an organization and deployed within owned facilities.

To improve the functioning of IT infrastructures, companies should improve service quality and hold its level in future [1], or change states resource

ISSN 2312-4121, Information and Telecommunication Sciences, 2015, Volume 6, Number 2

(C) 2015, National Technical University of Ukraine "Kyiv Polytechnic Institute" 
dependencies manifest the behavior of the infrastructure taking into technologies [2], hardware [3] or using specific mechanisms such as MPLS [4].

Telecom operators use various control systems of their IT infrastructure for efficient utilization of telecommunications infrastructure resources, monitoring and control of services provided level. One of the tasks of such systems is to estimate current quality level of service (QoS) or IT infrastructure functioning generally. There are many methods for evaluating the quality of functioning [5]. In work [6] has been already described an algorithm for evaluating the service quality. Neural networks have proven themselves most successfully. They are often used to estimate the individual elements, because there are many algorithms for their training, based on back propagation primarily. For example, in work [7] author proposes an improved online quasi-Newton method for robust training. And in another his work [8] is proposed an improved novel robust training algorithm based on quasi-Newton. Author proposed to associate by a weighting coefficient parameter online and batch error functions.

The author of this work [9] has studied problem of estimation of weights to combine trained neural networks using linear estimation techniques. He has investigated the problem of input feature selection and appropriate weight estimation in combining trained neural network through the information theory and linear estimation weight techniques.

But in a complex IT infrastructure with mutual influence of its elements, before neural networks training based on these methods, it is important to choose a structure of neural networks. Since there are a large number of IT infrastructure elements, this choice need to be automated.

To construct the optimal structure of the neural network [10] a wide range of algorithms is used. The first of these algorithms is tiled construction algorithm [11]. The idea of the algorithm is in addition of new layers of neurons so that the input training vectors, which have different respective initial values, had different internal representation in it. Another great algorithm is called algorithm of fast superstructure [12]. New neurons in this algorithm are added between the output layers. The role of these neurons is correction of output neurons errors.

In general, a neural network, which is based on this algorithm, has the form of a binary tree. Widely known algorithms based on B-trees are Monoplan, NetLines and NetSphere [13], the reduction method [6].

In work [14] is simply proposed a specific structure of neural networks with four layers used for specific tasks.

\section{Qualitative evaluation method of IT infrastructure functioning}

The aim of this work is to develop a method that evaluates a quality of IT infrastructure functioning, taking into account possible extension or modification of infrastructure.

The processes inside IT infrastructure aren't always described or fully formalized, and not explored at all in some cases. The developed method uses neural networks for evaluating quality of functioning because neural networks are able to identify the complex relationship between input data and output data, and perform a generalization. It means that in case of successful training the neural network will be able to return a correct result based on the data that was missing in the training set, or based on incomplete or noisy, partly corrupted data.

IT infrastructure is evolving and changing over time. Therefore, a neural network trained on outdated information will produce incorrect assessment. With the change of processes within the infrastructure not only weights coefficients of the neural network, but the neural network structure may need to be changed too. Therefore, the proposed method uses structural neural network training. It allows adapting to the dynamic changes within IT infrastructure.

Proposed algorithm for evaluation of IT infrastructure functioning quality consists of several consecutive steps:

1. Determining dependencies between the IT infrastructure elements. At this step what affects the IT infrastructure elements (or services provided by it, or IT infrastructure in general) is determined.

2. Monitoring. At this step, occurs the collection of information about functioning of the IT infrastructure elements. Here we form our database which will be used as input information for neural network training.

3. Training. At this step structure and weight coefficients of neural networks are determined. After this step we will have trained $\mathrm{NN}$ which will be used for IT functioning evaluation.

4. Evaluation of the quality of functioning. At this step the quality of the IT infrastructure functioning, based on the data collected in step 2 is evaluated. Our trained NN classifier will tell us about quality of IT functioning for new input operation states.

Listed steps are considered in more detail below.

\section{Determining dependencies between the IT infrastructure elements and collecting of data}

The aim of this article is to develop a model for evaluation quality of functioning of IT infrastructure elements with consideration of logical structure of the relationships between IT infrastructure elements. The results of this assessment in the future can be used for automatic or automated control of IT infrastructure elements in order to improve the quality of provided services [15].

Figure 1 shows the example of dependency graph which is schematically represents the impact of IT infrastructure elements. 


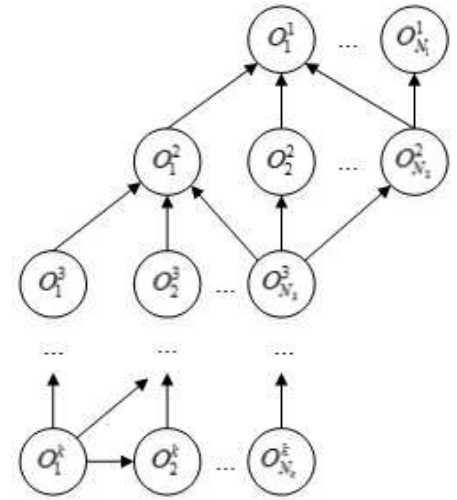

Figure 1. IT infrastructure elements impact graph

Here $O_{j}^{i}, \quad i \in[1 ; \mathrm{K}], \quad j_{i} \in\left[1 ; N_{i}\right]-$ IT infrastructure elements, and directed edges shows influence of some IT infrastructure elements on functioning of other element.

Denote vector of parameters that affect thequality of IT infrastructure element $O_{j}^{i}$, as $P_{j}^{i}$ and $Q_{j}^{i}$ as qualitative assessment of IT infrastructure elements functioning that are affect to $O_{j}^{i}$.

As an example of IT infrastructure element, was taken a developer computer. Reviewed five parameters affecting the quality of its functioning that are construct sets $P^{\prime}$ and $Q^{\prime}$ :

- $\quad \mathrm{p} 1$ - degree of using hard drive;

- $\quad \mathrm{p} 2$ - degree of using processor;

- p3 - load of network that computer is connected to;

- $\quad$ p4 - used computer RAM (value is defined as used RAM volume to maximum available memory ratio).

Those parameters are reduced to values between 0 and 1

- $\quad \mathrm{q} 1$ - quality of DB server functioning, used by selected computer.

To calculate the qualitative assessment of the functioning of this IT infrastructure element we construct a classifier based on neural network. For $O_{j}^{i}$ the input parameters of this neural network will be vector $\left\{P^{\prime}, Q\right\}$ and the output parameter is qualitative assessment of the functioning of $O_{j}^{i}$.

With absence of assumptions about the nature of relationships between elements and qualitative evaluations of elements parameters, it is advisable to apply approximate expert estimates based on personal experience of administrators, IT-managers, etc. Since we automatically determine the structure of the network, the person is enough to specify the quality of functioning of the element with different values of $\left\{P^{\prime}, Q^{\prime}\right\}$.

During experiment values of selected parameters were artificially set on computers. Then, it was proposed to experts to specify the performance of this computer on a scale from 0 to 1 .

For our aims was collected information about 100 node parameters for 2 weeks period in 2 hrs interval. After collecting was constructed dataset for $\mathrm{NN}$ in the form of vector $\left\{P_{i}, Q\right\}$. Next step is a design of $\mathrm{NN}$ classifier.

\section{Structural optimization algorithm for training of neural network}

Any neural network can be represented as a graph. The multilayer neural network architecture is an acyclic graph G, represented as a set of nodes, which are grouped into clusters by layers and connections between them. An example of such a neural network representation is shown in Figure 2.

Each node $L_{i}^{j}$ represents elementary neuron or element of more complex architecture, such as a small neural network (Figure 3).

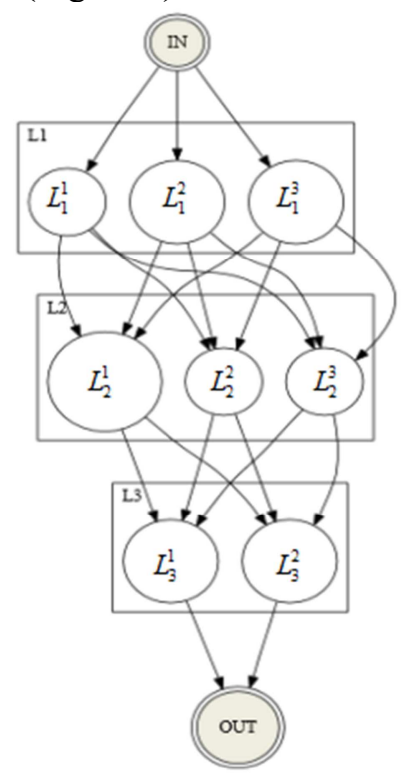

Figure 2. Graph model of neural network

The proposed algorithm of structural training of network allows:

- getting the overall structure of the neural network

- determining the number of neurons in the layers of the neural network

- removing non-significant connections between neurons (synapses)

- accelerating the training of neural network

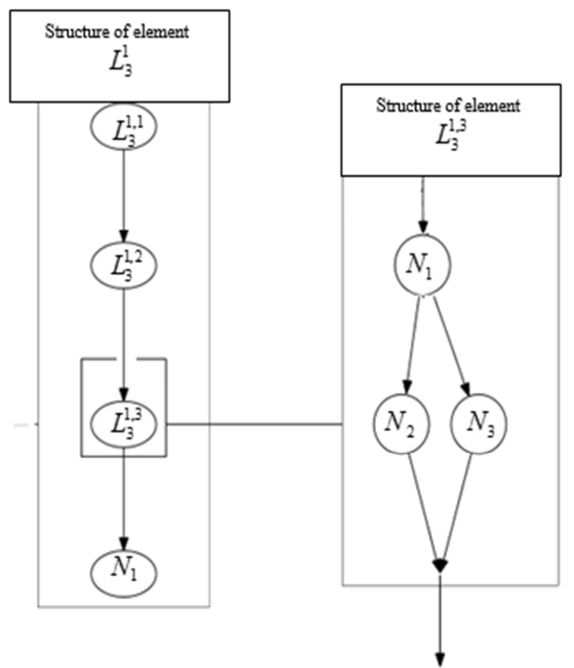

Figure 3. Structure of node 
The basic structural operations on the network:

- $S y n_{A D D}$ operation - adding a synapse between two randomly selected unrelated nodes or neurons network;

- $S y n_{D E L}$ operation - deleting the synapse between two randomly selected unrelated nodes or neurons network;

- $S y n_{M O D}$ operation - moving the synapse between two randomly selected unrelated nodes or neurons network;

- $A_{M O D}$ operation - changing the activation function of the neuron to randomly selected neuron;

- $\operatorname{Ser}_{N O D E}$ and $\operatorname{Ser}_{N R}$ operations - serialization of node or neuron;

- $\operatorname{Par}_{N O D E}$ and Par $_{N R}$ operations - parallelization of node or neuron;

- $A d d_{N O D E}$ and $A d d_{N R}$ operations - adding a node or neuron;

- $L_{A D D}$ operation - creating a new layer;

- $L_{D E L}$ operation - removing of HM layer.

Let's look into operations in more detailed way. Our network is set as the following graph:

$$
\mathrm{G}=\{\mathrm{V}, \mathrm{E}\}
$$

where

$V$ - the set of nodes and neurons;

$E$ - set of synapses that bind them;

Operation of addition synapse between two randomly selected unrelated nodes or neurons network is illustrated in Figure 4.

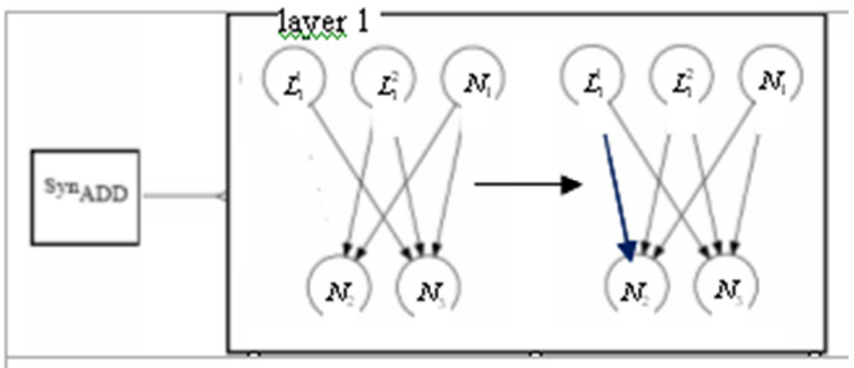

Figure 4. $\operatorname{Syn}_{A D D}$ operation

Let's define subset of nodes that belong to the previous sub-level as $V_{A}$ (synapses are coming out of them) and subset of nodes that belong to the next sublevel as $V_{B}$ (synapses are coming into them);

$$
\begin{aligned}
& E(G)=E(G) \cup(l, n) \\
& V_{A}=\left\{L_{1}^{1}, L_{1}^{2}, L_{1}^{3}\right\}, V_{B}=\left\{N_{1}, N_{2}\right\}, \\
& l \in V_{A}, n \in V_{B} .
\end{aligned}
$$

Operation of deletion synapse between two randomly selected nodes or neurons connected network shown in Figure 5.

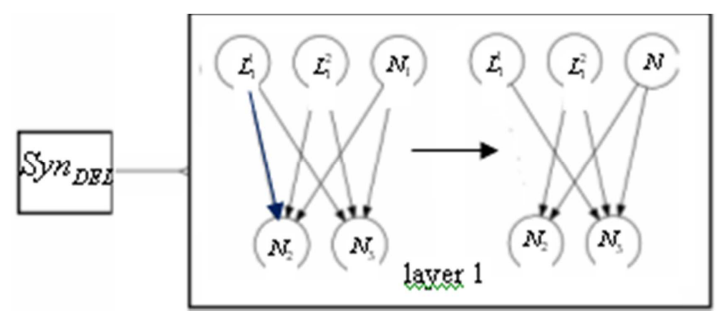

Figure 5. $\operatorname{Syn}_{D E L}$ operation

$$
\begin{aligned}
& E(G)=E(G) \backslash(l, n) \\
& V_{A}=\left\{L_{1}^{1}, L_{1}^{2}, L_{1}^{3}\right\}, V_{B}=\left\{N_{1}, N_{2}\right\}, \\
& l \in V_{A}, n \in V_{B} .
\end{aligned}
$$

Operation of movement of the synapse between two randomly selected nodes or neurons network is shown in Figure 6.

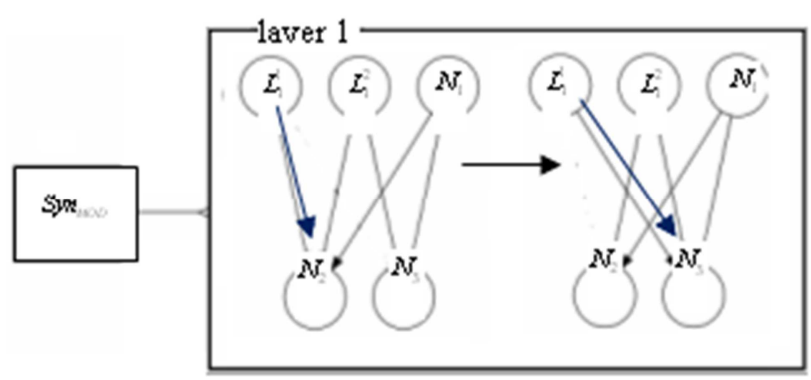

Figure 6. $\operatorname{Syn}_{M O D}$ operation

$$
\begin{aligned}
& E(G)=E(G) \backslash(l, n) ; \\
& E(G)=E(G) \cup(l, m) ; \\
& V_{A}=\left\{L_{1}^{1}, L_{1}^{2}, L_{1}^{3}\right\}, V_{B}=\left\{N_{1}, N_{2}\right\}, \\
& l \in V_{A}, n, m \in V_{B} .
\end{aligned}
$$

Operation of serialization $\mathrm{Ser}_{N O D E}$ and $\mathrm{Ser}_{N R}$ randomly selected node or neuron network is shown in Figure 7.

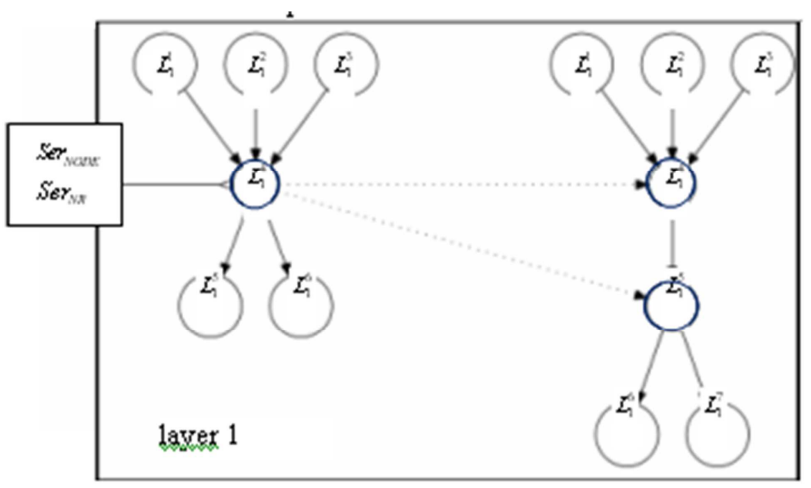

Figure 7. Operation of serialization 


$$
\begin{aligned}
& E(G)=E(G) \backslash \forall(l, n) ; \\
& V_{A}=\left\{L_{1}^{4}\right\}, V_{B}=\left\{L_{1}^{S}, L_{1}^{6}\right\}, l \in V_{A}, n \in V_{B} \\
& V(G)=V(G) \cup L_{1}^{5}(\quad \text { reindexing }) \\
& V_{B}^{\prime}=\left\{L_{1}^{6}, L_{1}^{7}\right\}, V_{A}^{\prime}=\left\{L_{1}^{5}\right\} \\
& E(G)=E(G) \cup(l, m) ; l \in V_{A}^{t}, m \in V_{B}^{t} \\
& E(G)=E(G) \cup(k, p) ; k \in V_{A}, p \in V_{A}^{\prime}
\end{aligned}
$$

Operation of parallelization $\operatorname{Par}_{N O D E}$ and $\operatorname{Par}_{N R}$ randomly selected node or neuron network is shown in Figure 8.

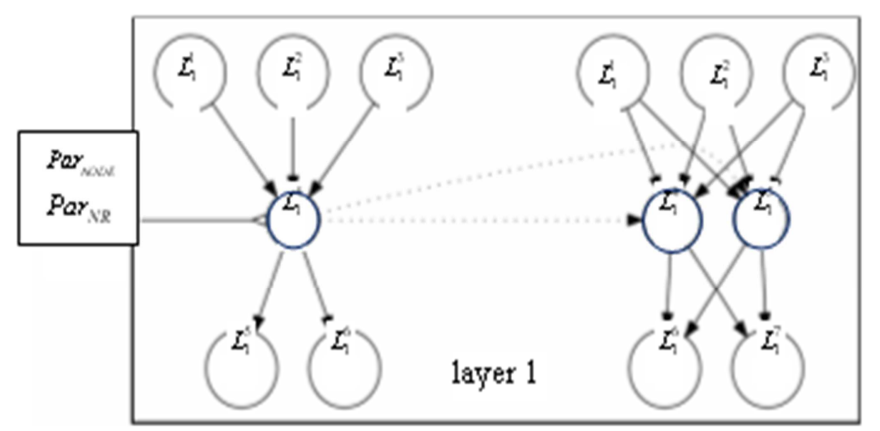

Figure 8. Operation of parallelization

$$
\begin{aligned}
& V(G)=V(G) \cup L_{1}^{s}(\quad \text { reindexing }) \\
& V_{B}^{t}=\left\{L_{1}^{6}, L_{1}^{7}\right\}, V_{A}=\left\{L_{1}^{1}, L_{1}^{2}, L_{1}^{3}\right\}, V_{A}^{t}=\left\{L_{1}^{s}\right\} \\
& E(G)=E(G) \cup(l, m) ; l \in V_{A}, m \in V_{A}^{t} \\
& E(G)=E(G) \cup(k, p) ; k \in V_{A}^{t}, p \in V_{B}^{t}
\end{aligned}
$$

Operation adding node or neuron $A d d_{N O D E}$ and $A d d_{N R}$ is shown in Figure 9.

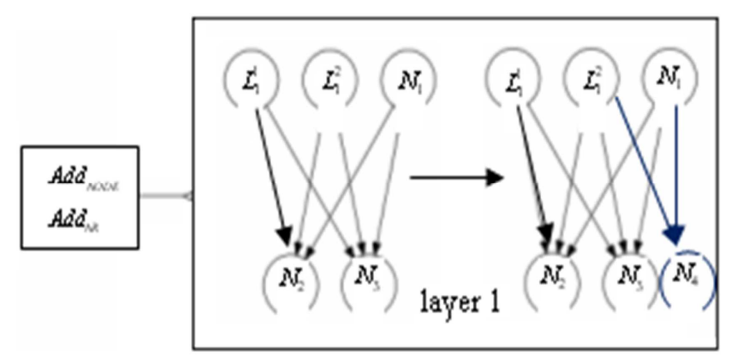

Figure 9. $\operatorname{Add}_{N O D E}$ and $\operatorname{Add}_{N R}$ operations

When adding a new node or neuron, few synapses in both directions created neuron or node are randomly added. Deleting a node is fulfilled with simultaneous deletion of all synapses that are included in this element. All relations that come out from this element randomly connect with elements followed by the removed ones. Operation of creating a new layer is a modifier for operations of adding node or neuron and operations of serialization and parallelization discussed above and indicates that the result of the operation adds to a new layer of network.
Consider the algorithm for structural optimization in training. As a basic learning algorithm let's take algorithm of reverse spreading of error which is proposed in [6].

$\mathrm{NN}$ has sigmoid activation function:

$$
f(u)=\frac{1}{1+e^{-u}},
$$

where

$$
u=w_{0}+w_{1} x_{1}+\ldots+w_{n} x_{n}
$$

We introduce the following notation: set of training data $X_{s}=\left\{x_{i} \mid i=1, \ldots, N\right\}$ and the corresponding expected values $Y_{s}=\left\{y_{i} \mid i=1, \ldots, M\right\}$, where $N$ - number of inputs of NN, $M$ - number of outputs, $s=1, \ldots, S$ and - dimension of the training set.

Denote the set of values of the outputs of $\mathrm{NN}$ neurons through $F_{i}=\left\{f_{j}\right\}$, where $i$ - number of layer and $j$ - number of neurons in the layer. For the input layer $j=1,2, \ldots, N$, for the first hidden layer $-j=1,2, \ldots, C_{l}$, second $-j=1,2, \ldots, C_{2}$ and so on, for the last hidden layer $-j=1,2, \ldots, M$.

The total number of $\mathrm{NN}$ layers equals $K$ and few neurons in all the hidden layers will be $C=\left\{C_{0}, C_{1}, \ldots, C_{K}\right\}$, where $C_{0}=N, C_{K}=M$.

Algorithm of reverse spreading of error can be represented as following:

1) For the input layer sets the value of each element according to input vector. The value of the output of each element we set equal to input.

$$
F_{0}=X_{1} \text {. }
$$

2) For the first layer neurons compute the total input and output:

$$
u_{j}^{1}=w_{j, 0}^{1}+\sum_{i=1}^{N} f_{i}^{0} w_{j, i}^{1}
$$

where

$$
f_{j}^{1}=\frac{1}{1+e^{-u_{i}^{i}}},
$$

where $j=1,2, \ldots, N_{1}-$ number of the neuron of the first hidden layer, $w_{j, i}^{l}-i$-th weight coefficient of $j$-th neuron of $l$-layer of $\mathrm{NN}, f_{i}^{0}$ - value of the $i$-th neuron in the input layer.

3) Repeat the first step for all of the hidden layers of $\mathrm{NN}$, including the output layer of neurons, but formulas (10) and (11) will be next:

$$
u_{j}^{k}=w_{j, 0}^{k}+\sum_{i=1}^{c_{k}} f_{i}^{c-1} w_{j, i}^{c},
$$

where

$$
f_{j}^{c}=\frac{1}{1+e^{-L_{i}^{e}}}
$$

where $c=2, \ldots, K$. 
4) Compare the values of the vectors $Y_{0}$ and $F_{K}$, if the difference between the vector - model $Y_{0}$ and NN real output $F_{K}$ is in acceptable range, then go to step 5, if not, go to step 6 .

5) For the input vector set value of each element, which equals to the corresponding element $X_{2}\left(F_{0}=X_{2}\right)$ and go back to step 2. If the input of $\mathrm{NN}$ gets the last vector $X_{S}$, then depending whether there is a necessary training on this iteration, we re-apply to the input all the training vectors starting from the first, or it's considered $\mathrm{NN}$ is trained and training ends.

6) For each neuron from the output layer, we calculate an error. As our $\mathrm{NN}$ is with sigmoid activation function, error equals :

$$
\delta_{i}=\left\{\begin{array}{c}
f_{i}^{1}\left(1-f_{i}^{1}\right)\left(y_{i}-f_{i}^{1}\right) n p u \mathrm{f}_{\mathrm{i}}<f_{i}^{1} \\
\mathrm{f}_{\mathrm{i}}\left(1-\mathrm{f}_{\mathrm{i}}\right)\left(y_{i}-\mathrm{f}_{\mathrm{i}}\right) n p u f_{i}^{\prime 2}<\mathrm{f}_{\mathrm{i}}<f_{i}^{1}, \\
f_{i}^{\prime 2}\left(1-f_{i}^{\prime 2}\right)\left(y_{i}-f_{i}^{\prime 2}\right) \text { npu } \mathrm{f}_{\mathrm{i}}>f_{i}^{\prime 2}
\end{array},\right.
$$

where $f_{i}$ - the resulting value of the $j$-th element output layer; $f_{\mathrm{i}}^{1}, f_{\mathrm{i}}^{2}$ - local extreme point to the expected value of $y_{i}$ in the range $[0,1]$.

7) Network mutations factor is calculated:

$$
M_{N E T}=\frac{1}{\delta(t+1)},
$$

Depending on the coefficients modification of the structure of neural network is performed by sing basic structural operations, discussed earlier (Table 1). Trend of estimated coefficient indicates the dynamics of learning. If in each training epoch it is growing, it means that that error decreases, there is no sense to change something in the structure of the network. Conversely, if the trend is falling, you need to modify the structure of the network.

Table 1. Usage of basic structural operations

\begin{tabular}{|c|c|c|}
\hline Value $\mathbf{M}_{\text {NET }}$ & Trend $\mathbf{M}_{\text {NET }}$ & \multicolumn{1}{c|}{ Operation } \\
\hline$>1$ & Growing & - \\
\hline$>1$ & Falling & $L_{A D D}$ \\
\hline$>100$ & Growing & - \\
\hline$>100$ & Falling & $\begin{array}{l}\operatorname{Ser}_{N O D E}, \text { Ser }_{N R}, \text { Par }_{N O D E}, \\
\operatorname{Par}_{N R}, \text { Add }_{N O D E}, A d d_{N R}\end{array}$ \\
\hline$>500$ & Growing & - \\
\hline$>500$ & Falling & Syn $_{A D D}$, Syn $_{M O D}, A_{M O D}$ \\
\hline
\end{tabular}

8) For the penultimate layer error of each neuron is calculated:

$$
\delta_{i}^{K-1}=f_{i}^{K-1}\left(1-f_{i}^{K-1}\right) \sum_{j=1}^{c_{X}} \delta_{j}^{K} w_{i, j}^{K-1},
$$

where $\delta_{j}^{K}$ - the error of $j$-th element of the $K$-th layer, $w_{i, j}^{K-1}$ - the weight of the connection between the $i$-th element of the $K$-1 layer and the $j$-th element of the $K$-th layer, $f_{i}^{K-1}$ - the value of $i$-th element of $K$-1 st layer.
9) For all other hidden layers of error is calculated by the formula (16).

10) Further, for all the layers weight coefficients of each neuron are updated.

$$
\Delta w_{i, j}^{c}(t+1)=\eta\left(\delta_{i}^{c} f_{j}^{c-1}\right)+\alpha \Delta w_{i, j}^{c}(t),
$$

where $\eta$-speed of training, $\alpha$-inertia, or the impact of the previous changes usually taken $\alpha<1, t$ - iteration number. Then we set the new value of weights coefficients, equal:

$$
w_{i, j}^{c}=w_{i, j}^{c}+\Delta w_{i, j}^{c}(t) \text {. }
$$

11) For the input vector sets value of each neuron that equals appropriate element $X_{2}\left(F_{0}=X_{2}\right)$ and again move to step 2 . If last vector $X_{S}$ have already filed to the input of NN, then again first training vector served.

\section{Evaluation of the quality of functioning}

For testing of the quality of functioning from our dataset was formed testing dataset consist of $40 \%$ elements.

Over 100 iterations of the algorithm were performed 645 deletions and 457 additions of synapses. The percentage of false classification was reduced from $7.8 \%$ to $6.0 \%$ against not optimized NN. Classification results are shown in Table 2 and Fig. 10.

Table.2. Classification results

\begin{tabular}{|l|c|c|}
\hline \multicolumn{1}{|c|}{ NN type } & Training, $\%$ & Testing, $\%$ \\
\hline Simple & 98.79 & 92.21 \\
\hline Optimized & 99.09 & 94.01 \\
\hline
\end{tabular}

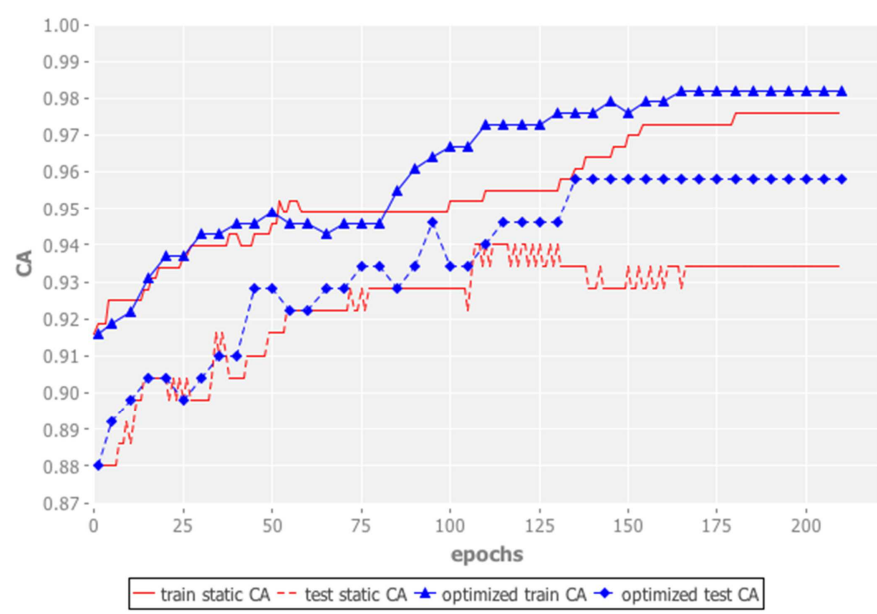

Figure 10. Classification results

This chart shows that the method described in this paper allows achieving more accurate results from the neural network training. This allows obtaining more accurate information about the IT infrastructure functioning. 


\section{Conclusions}

IT companies are faced with problems related to improving the quality of the operation of their IT infrastructure. One of the ways is to improve quality and hold this level in future, another - is to change states resource dependencies manifest the behavior of the infrastructure. When solving problems as well as maintaining certain parameters of IT infrastructure elements and services on a sufficient quality level of functioning, it is important to ensure and control the required functioning quality of IT infrastructure executive elements. It is necessary to determine whether the system and its modules are in the desired range of quality of functioning, based on data from monitoring of executive modules.

This paper proposes to use neural networks to evaluate a quality of IT infrastructure functioning. Since the task of determining the structure of the neural network is almost impossible, because it requires a deep analysis of each processes taking place in the IT infrastructure, the paper proposes to define the structure of the neural network automatically using structural optimization algorithm of neural network. The existence of such method would allow getting the structure of the neural network that would be best-answered domain and available input data quickly

In addition, a series of experiments constructed algorithm that demonstrate the ability to use it in problems of classification of data.

The proposed method makes it possible to control processes inside IT-infrastructure and to form the control actions taking into account the quality of the functioning of IT-infrastructure components which makes it advisable to use a control loop targeted at improving the quality indicators of the performance of the IT-infrastructure.

Also the resulting structure of neural network can be used in quality estimation of similar IT infrastructure elements functioning. This will allow the service provider "on the fly" construct and retrain its existing models in a shorter period.

\section{References}

1. Scheibenberger, K. Modelling dependencies of IT Infrastructure elements / Scheibenberger, K., Pansa, I. // Business-driven IT Management, 2008. BDIM 2008. 3rd IEEE/IFIP International Workshop on 7-7 April 2008 p. 112-113

2. Richardson, P. Quality of service support for wireless Internet service providers / Richardson, P., Sieh, L., Ganz, A. // Computer Communications and Networks, 2001. Proceedings. Tenth International Conference on 2001. - p. 318-323

3. da Silva, L.F. An IT Infrastructure Patterns Approach to Improve IT Service Management Quality / da Silva, L.F., Brito e Abreu, F. // Quality of Information and Communications Technology (QUATIC), 2010 Seventh International Conference on the Sept. 29 2010-Oct. 22010 p. $171-176$

4. Toguyeni, A. Quality of service of internet service provider networks: State of the art and new trends /
Toguyeni, A., Korbaa, O. // ICTON Mediterranean Winter Conference, ICTON-MW $2007-2007-$ p. 1-8

5. Donko, D. Improvement of the process quality in the service provider organization // Telecommunications (BIHTEL), 2014 X International Symposium on - $2014-\mathrm{p}$. $1-5$

6. Telenyk S. Qualitative evaluation method of ITinfrastructure elements functioning // Telenyk S., Rolick O., Bukasov M., Dorogiy Y., Halushko D., Pysarenko A. / IEEE International Black Sea Conference on Communications and Networking (BlackSeaCom) / 2014, P 170-174

7. Hiroshi Ninomiya, An Improved Online quasiNewton method for robust training and its application to microwave neural network models // Neural Networks (IJCNN), The 2010 International Joint Conference on 18-23 July $2010-$ p. $1-8$

8. Hiroshi Ninomiya Parameterized online quasiNewton training for high-nonlinearity function approximation using multilayer neural networks / Hiroshi Ninomiya // Neural Networks (IJCNN), The 2011 International Joint Conference on July 31 2011-Aug. 52011 -p. $2770-2777$

9. Qazi, N. Estimation of weights to combine trained neural networks using linear estimation techniques / Qazi, N.// Multitopic Conference (INMIC), 2011 IEEE 14th International $-2001-\mathrm{p} 1-7$

10. Hayashida, T. Structural optimization of neural network for data prediction using dimensional compression and tabu search / Hayashida, T., Nishizaki, I. ; Matsumoto, T. // Computational Intelligence \& Applications (IWCIA), 2013 IEEE Sixth International Workshop on 13-13 July 2013 - p. $85-88$

11. Mezard M., and Nadal J.P. Learning in feedforward layered networks: The Tiling algorithm // Journal of Physics. - 1989. - V. A22. - P. 2191 - 2203, Frean M. The Upstart Algorithm: A Method for Constructing and Training FeedForward Neural Networks // Tech. Rep. 89/469, Edinburgh Univ., 1989.

12. Ash T. Dynamic Node Creation in BackPropagation Networks // Connection Science. - 1989. - V. 1. Mozer M.C., Smolensky P. Skeletonization: a technique for trimming the fat from a network via relevance assessment // Advances in Neural Information Processing Systems. 1989. - V. 1. - P. 107 - 115.

13. Dorogyy Y.Y. Uskorennyiy algoritm obucheniya svertochnyih neyronnyih setey (Accelerated learning algorithm of Convolutional neural networks)/Y.Y.Dorogiy // Visnyk NTUU «KPI». Informatyka, upravlinnya ta obchyslyuval'na tekhnika. - K.: «VEK+»

14. Hayashida, T. Structural optimization of neural networks and training data selection method for prediction / Hayashida, T., Nishizaki, I. ; Sekizaki, S. ; Nishida, M. // Computational Intelligence and Applications (IWCIA), 2014 IEEE 7th International Workshop on 7-8 Nov. $2014-p$. $171-176$

15. Telenyk S.F. Resource allocation and load management considering the assessed quality of the provided service and the use of agent technologies / S.F. Telenyk, A.I. Rolik, A.A. Pokotylo // 23rd International Crimean Conference "Microwave \& Telecommunication Technology" (CriMiCo'2013). 9-13 September, Sevastopol, Crimea, Ukraine. -2013 . - p. 535-536.

Received in final form on April 20, 2015 
Дорогий І.І, Теленік С.Ф., Галушко Д.А. Цуркан В.В.

Структурна оптимізація нейронної мережі на основі методу якісної оцінки функціонування IT-інфраструктури

Проблематика. У теперішній час нейронні мережі широко використовуються для вирішення різних завдань. У зв'язку з цим проблема розробки алгоритму навчання, який був би здатний динамічно оптимізувати структуру нейронних мереж, дуже важлива. Наявність такого способу дозволить дослідникам отримати структуру нейронної мережі, яка забезпечувала б швидкий доступ до вхідних даних. ІТ-інфраструктура дозволяє надавати організації ITрішення і послуги для своїх співробітників або клієнтів та, як правило, є внутрішньою для організації і розгортається на тих об'єктах, які їй належать.

Мета досліджень.У більшості випадків, організації можуть управляти окремими елементами в межах своєї ITінфраструктури. Проте заздалегідь треба оцінити поточний рівень якості обслуговування (QoS) або функціонування IT-інфраструктури в цілому. У комплексі IT-інфраструктури із-за взаємного впливу елементів важко оцінити ії якість або умови ії експлуатації.

Методика реалізації. Для ІТ-інфраструктури, що складається з великої кількості елементів, важливо вибрати структуру для нейронних мереж автоматично. Запропонований метод дозволяє контролювати процеси усередині ITінфраструктури і формувати управляючи дії, зважаючи на якість функціонування компонентів IT-інфраструктури, що робить доцільним використання контуру управління, спрямованого на поліпшення якісних показників функціонування ИТ-інфраструктури.

Результати досліджень. У статті пропонується використати нейронні мережі для оцінки якості функціонування IT-інфраструктури. Оскільки завдання визначення структури нейронної мережі практично вирішити неможливо, тому що це вимагає глибокого аналізу кожного з процесів, що відбуваються в ІТ-інфраструктурі, запропоновано визначати структуру нейронної мережі автоматично за допомогою структурного алгоритму оптимізації нейронної мережі. Проведена серія експериментів з побудованим алгоритмом, яка продемонструвала здатність використання його в завданнях класифікації даних.

Висновки. В результаті реалізації запропонованого методу структура нейронної мережі може бути використана при оцінці якості функціонування схожих елементів ІТ-інфраструктури. Це дозволить постачальникові послуг "на льоту" створювати і перенастроювати свої існуючі моделі в коротший термін.

Ключові слова: IT інфраструктура; нейронні мережі; контроль процесів; оцінка якості.

Дорогий И.И, Теленик С.Ф., Галушко Д.А. Цуркан В.В.

Структурная оптимизация нейронной сети на основе метода качественной оценки функционирования ИТ инфраструктуры

Проблематика. В настоящее время нейронные сети широко используются для решения различных задач. В связи с этим проблема разработки алгоритма обучения, который был бы способен динамически оптимизировать структуру нейронных сетей, очень важна. Наличие такого способа позволит исследователям получить структуру нейронной сети, которая обеспечивала бы быстрый доступ к входным данным. ИТ-инфраструктура позволяет предоставлять организации ИТ-решения и услуги для своих сотрудников или клиентов и, как правило, является внутренней для организации и разворачивается на принадлежащих ей объектах.

Цель исследований. В большинстве случаев, организации могут управлять отдельными элементами в пределах своей ИТ-инфраструктуры. Однако предварительно нужно оценить текущий уровень качества обслуживания (QoS) или функционирования ИТ-инфраструктуры в целом. В комплексе ИТ-инфраструктуры из-за взаимного влияния элементов трудно оценить ее качество или условия ее эксплуатации.

Методика реализации. Для ИТ-инфраструктуры, состоящей из большого количества элементов, важно выбрать структуру для нейронных сетей автоматически. Предложенный метод позволяет контролировать процессы внутри ИТинфраструктуры и формировать управляющие воздействия, принимая во внимание качество функционирования компонентов ИТ-инфраструктуры, что делает целесообразным использование контура управления, направленного на улучшение качественных показателей функционирования ИТ-инфраструктуры.

Результаты исследований. В статье предлагается использовать нейронные сети для оценки качества функционирования ИТ-инфраструктуры. Поскольку задачу определения структуры нейронной сети практически решить невозможно, потому что это требует глубокого анализа каждого из процессов, происходящих в ИТинфраструктуре, предложено определять структуру нейронной сети автоматически с помощью структурного алгоритма оптимизации нейронной сети. Проведена серия экспериментов с построенным алгоритмом, которая продемонстрировала способность его использования в задачах классификации данных.

Выводы. В результате реализации предложенного метода структура нейронной сети может быть использована при оценке качества функционирования сходных элементов ИТ-инфраструктуры. Это позволит поставщику услуг "на лету" создавать и перенастраивать свои существующие модели в более короткий срок.

Ключевые слова: ИТ инфраструктура; нейронные сети; контроль процессов; оценка качества. 